\title{
Feeding Strategies for Enrichment and Characterization of Anammox Biomass in a Sequencing Batch Reactor
}

\author{
Tiago H. Martins*, Theo S. O. Souza, Maria Bernadete Amâncio Varesche \\ Department of Hydraulics and Sanitation, São Carlos School of Engineering (EESC), University of São Paulo \\ (USP), São Carlos, Brazil \\ Email: ${ }^{*}$ dr.thmartins@gmail.com
}

Received 23 July 2014; revised 8 September 2014; accepted 23 September 2014

Copyright (C) 2014 by authors and Scientific Research Publishing Inc.

This work is licensed under the Creative Commons Attribution International License (CC BY).

http://creativecommons.org/licenses/by/4.0/

(c) () Open Access

\begin{abstract}
Anammox bacteria represent a promising alternative for treating ammonium-rich wastewater. In this work reported, biomass performing anaerobic oxidation of ammonium was enriched in a sequencing batch reactor, from sludge used for the treatment of high-nitrogen waste from an amino acid-producing industry. After 89 days of operation, both ammonium and nitrite were consumed. During operation under a 24-hour cycle, the applied nitrogen load (ANL) was increased from 155 to $802 \mathrm{mg} \mathrm{N} / \mathrm{L} \cdot d$. This strategy resulted in efficiencies of nitrogen removal and nitrogen conversion rate of $91.7 \%$ and $98.5 \%$, respectively. Specific anammox activity increased proportionally to ANL and it was partially inhibited at $802 \mathrm{mg} \mathrm{N} / \mathrm{L} \cdot d$. Sequencing analysis using 16S rRNA anammox primers, after 170 days of operation, showed that 21 clones were grouped into two OTUs (operational taxonomic units). The identity of the $16 \mathrm{~S}$ rRNA gene of OTU esp 1 showed similarity to Brocadia species, and OTU esp 2 displayed 99\% similarity to Anammoxoglobus propionicus. After 450 days of operation, sequencing analysis using universal primers showed that 48 clones were grouped into 19 OTUs representing six major groups of bacteria: Planctomycetes, beta-Proteobacteria, green sulfur bacteria of the Chlorobi phylum, Nitrospira, Chloroflexi and OP 11. Brocadia sp. was the only anammox bacteria in the biomass at this time.
\end{abstract}

Keywords

Ammonium, Nitrite, Anammox, Anammoxoglobus sp., Brocadia sp., Nitrogen

\section{Introduction}

Nitrogen discharges in water bodies are a constant matter of concern due to the environmental and public health ${ }^{*}$ Corresponding author.

How to cite this paper: Martins, T.H., Souza, T.S.O. and Varesche, M.B.A. (2014) Feeding Strategies for Enrichment and Characterization of Anammox Biomass in a Sequencing Batch Reactor. American Journal of Analytical Chemistry, 5, 891-900. http://dx.doi.org/10.4236/ajac.2014.514097 
issues they create. Nitrogen compounds cause eutrophication, mainly due to the excessive growth of algal biomass, and ammonia is toxic to aquatic organisms. Moreover, ammonium is oxidized to nitrate, decreasing the amount of dissolved oxygen in aquatic ecosystems and causing mortality of the aerobic biota. Concerning human health, the ingestion of nitrate can cause irreversible conversion of hemoglobin to methemoglobin, leading to respiratory disorders. Therefore, the development of efficient technologies for nitrogen removal from effluents is of paramount importance.

Conventionally, the nitrification-denitrification process has been employed for nitrogen removal in wastewater treatment plants. However, the need for supplementing the wastewater with organic electron donors for denitrification, increased sludge yields and high aeration costs for producing nitrates are clear drawbacks that have been promoting the search for alternative and cost-effective technologies. In this context, the anammox (anaerobic ammonium oxidation) process has spurred interest for nitrogen removal, since ammonium can be oxidized by autotrophic microorganisms without the addition of molecular oxygen [1]. The anammox reaction involves ammonium oxidation using nitrite as electron acceptor and produces dinitrogen gas. Therefore, this process is extremely advantageous when it is coupled to short nitrification (nitritation). Compared to conventional nitrification/denitrification, the nitritation/anammox system saves $50 \%$ on required oxygen, $100 \%$ on the external carbon source and $80 \%$ in biomass management [2].

One of the main issues regarding the anammox process is obtaining biomass, since anammox bacteria cannot be cultivated by conventional microbiological techniques [3]. The phylogenetic $16 \mathrm{~S}$ gene approach identified anammox bacteria as autotrophic and related to the Planctomycetes phylum. It was previously believed that the Planctomycetes had limited environmental relevance, but microbial ecology studies have shown that this bacteria group is ubiquitous [3]. In this way, more information on enrichment processes and phylogeny for anammox biomass must be acquired.

In the present study, anammox biomass was enriched from a nitrifying-denitrifying reactor sludge using different feed strategies in a Sequencing Batch Reactor (SBR), and the 16S gene approach (using both specific and universal primers) was used to assess the biomass phylogeny with regard to anammox bacteria and Bacteria domain. Additionally, specific anammox activity was measured on steady state reactor operation.

\section{Material and Methods}

\subsection{Operation of the Sequencing Batch Reactor}

The enrichment of anammox biomass was carried out in a SBR for its biomass retention, simplicity and homogeneity of mixture. The reactor consisted of a borosilicate glass with a diameter of $20.3 \mathrm{~cm}$ and a height of 17 $\mathrm{cm}$. A six-bladed turbine carried out stirring at $50 \mathrm{rpm}$ (each blade with length of $6.8 \mathrm{~cm}$ and height of $2 \mathrm{~cm}$ ). The temperature was maintained at $37^{\circ} \mathrm{C} \pm 1{ }^{\circ} \mathrm{C}$, which presented the highest anammox activity according to [4]. The total volume of SBR was $5 \mathrm{~L}$, and $3 \mathrm{~L}$ was discarded from each batch. The reactor was inoculated with $2 \mathrm{~L}$ of sludge from an anaerobic-aerobic reactor employed in the treatment of an amino acid-producing industry (Ajinomoto, Pederneiras/SP, Brazil) [5].

In the first 45 days of operation, pure argon (99.95\%) was flushed in reactor bulking, to achieve anaerobiosis (20 mL/min). The effluent $\mathrm{pH}$ exhibited values of up to 9.1, which was higher than the optimal values observed for the anammox process [6]. Because of the high effluent $\mathrm{pH}$, pure argon was replaced by an $\mathrm{Ar} / \mathrm{CO}_{2}(97 \% / 3 \%)$ mixture for $\mathrm{pH}$ control and as a supplemental carbon source from the $45^{\text {th }}$ day of operation on. This $\mathrm{Ar} / \mathrm{CO}_{2}$ mixture was continuously flushed into the reactor headspace, to prevent the entry of oxygen, from the $89^{\text {th }}$ day of operation on.

Five feeding strategies were carried out (Table 1). Under strategy $S_{1}$, filling step was set to 12 hours to avoid nitrite accumulation in the reactor, which can inhibit the anammox process, with a $56 \mathrm{~h}$ cycle (3-cicle/week). Under strategy $\mathrm{S}_{2}$, the reaction step was adjusted from $240 \mathrm{~h}(10 \mathrm{~d})$ to $48 \mathrm{~h} \mathrm{(2} \mathrm{d),} \mathrm{since} \mathrm{the} \mathrm{reactor} \mathrm{was} \mathrm{manually}$ fed when it was observed total consumption of nitrite. Strategy $S_{3}$ comprised a cycle of $168 \mathrm{~h}$ (one-cicle/week) with constant filling (except during settling and discharging), aiming for the growing of biomass, in this strategy the weekly Applied Nitrogen Load (ANL) was the similar to strategy $S_{1}$. As the increase of biomass was not observed, feeding strategy (similar to $S_{2}$ ) was again employed for total consumption of nitrite (strategy $\mathrm{S}_{4}$ ). Under strategy $S_{5}$, the reactor was initially filled over $2.5 \mathrm{~h}$, operating with a $24 \mathrm{~h}$ cycle and the influent $\mathrm{NO}_{2}^{-}-\mathrm{N} / \mathrm{NH}_{4}^{+}-\mathrm{N}$ ratio changed to approximately stoichiometric requirements (Table 2).

The SBR was fed with basal medium adapted from [7]. The ammonium and nitrite concentrations ranged 
Table 1. Feeding strategies employed during the operation of the SBR.

\begin{tabular}{|c|c|c|c|c|c|}
\hline \multirow{2}{*}{ SBR operation } & \multicolumn{5}{|c|}{ Strategy } \\
\hline & $\mathrm{S}_{1}$ & $\mathrm{~S}_{2}$ & $\mathrm{~S}_{3}$ & $\mathrm{~S}_{4}$ & $\mathrm{~S}_{5}$ \\
\hline Filling & $0-12 h$ & $0-0.25 \mathrm{~h}$ & $0-167.5 \mathrm{~h}$ & $0-0.25 \mathrm{~h}$ & $0-2.5 \mathrm{~h}$ \\
\hline Reaction & $0-55.5 \mathrm{~h}$ & $(48-240 h)^{1}$ & $0-167.5 \mathrm{~h}$ & $0-47.5 \mathrm{~h}$ & $0-23.5 \mathrm{~h}$ \\
\hline Settling & $55.5-55.83 h$ & $(0.33 \mathrm{~h})^{1}$ & 167.5 - $167.83 \mathrm{~h}$ & $47.5-47.83 h$ & $23.5-23.83 h$ \\
\hline Discharging & $55.83-56 h$ & $(0.17 \mathrm{~h})^{1}$ & 167.83 - 168 h & $47.83-48$ h & $23.83-24$ h \\
\hline Operation period ${ }^{1}$ & $\begin{array}{c}1^{\text {st }}-89^{\text {th }} \text { day } \\
(89 \text { d) }\end{array}$ & $\begin{array}{c}90^{\text {th }}-120^{\text {th }} \text { day } \\
(31 \text { d) }\end{array}$ & $\begin{array}{c}121^{\text {st }}-179^{\text {th }} \text { day } \\
(59 d)\end{array}$ & $\begin{array}{c}180^{\text {th }}-214^{\text {th }} \text { day } \\
(35 d)\end{array}$ & $\begin{array}{c}215^{\text {th }}-543^{\text {rd }} \text { day } \\
(329 \text { d) }\end{array}$ \\
\hline
\end{tabular}

${ }^{1}$ Total time of strategies.

Table 2. Ammonium and nitrite concentrations in each strategy.

\begin{tabular}{|c|c|c|c|c|c|}
\hline Strategy & Ammonium (mg $\left.\mathrm{NH}_{4}^{+}-\mathrm{N} / \mathrm{L}\right)$ & Nitrite (mg $\left.\mathrm{NO}_{2}^{-}-\mathrm{N} / \mathrm{L}\right)$ & Duration & Influent & $\mathrm{NO}_{2}^{-}-\mathrm{N} / \mathrm{NH}_{4}^{+}-\mathrm{N}$ ratio \\
\hline $\mathrm{S}_{1.1}$ & $77 \pm 7$ & $72 \pm 12$ & $1^{\text {st }}-55^{\text {th }}$ day & & $0.93 \pm 0.14$ \\
\hline $\mathrm{S}_{1.2}$ & $34 \pm 2$ & $33 \pm 1$ & $56^{\text {th }}-89^{\text {th }}$ day & & $0.96 \pm 0.08$ \\
\hline $\mathrm{S}_{2}$ & $32 \pm 13^{1}$ & $30 \pm 18^{1}$ & $90^{\text {th }}-120^{\text {th }}$ day & & $0.89 \pm 0.18$ \\
\hline $\mathrm{S}_{3}$ & $49 \pm 13^{2}$ & $24 \pm 9^{2}$ & $121^{\text {st }}-179^{\text {th }}$ day & & $1.02 \pm 0.02$ \\
\hline $\mathrm{S}_{4}$ & $67 \pm 17$ & $64 \pm 19$ & $180^{\text {th }}-214^{\text {th }}$ day & & $0.95 \pm 0.2$ \\
\hline $\mathrm{S}_{5.1}$ & $71 \pm 4$ & $84 \pm 5$ & $215^{\text {th }}-287^{\text {th }}$ day & & $1.17 \pm 0.1$ \\
\hline $\mathrm{S}_{5.2}$ & $140 \pm 6$ & $174 \pm 8$ & $288^{\text {th }}-336^{\text {th }}$ day & & $1.24 \pm 0.05$ \\
\hline $\mathrm{S}_{5.3}$ & $223 \pm 8$ & $281 \pm 9$ & $337^{\text {th }}-434^{\text {th }}$ day & & $1.26 \pm 0.05$ \\
\hline $\mathrm{S}_{5.4}$ & $285 \pm 5$ & $334 \pm 14$ & $435^{\text {th }}-470^{\text {th }}$ day & & $1.17 \pm 0.03$ \\
\hline $\mathrm{S}_{5.5}$ & $346 \pm 7$ & $456 \pm 14$ & $471^{\text {st }}-546^{\text {th }}$ day & & $1.31 \pm 0.02$ \\
\hline
\end{tabular}

${ }^{1}$ Ammonium and nitrite concentrations increased from $26 \pm 4$ to $65 \mathrm{mg} \mathrm{NH}_{4}^{+}-\mathrm{N} / \mathrm{L}$ and from $23 \pm 6$ to $80 \mathrm{mg} \quad \mathrm{NO}_{2}^{-}-\mathrm{N} / \mathrm{L}$ at last batch of strategy $\mathrm{S}_{2}$.

${ }^{2}$ Mean concentration in the reactor. Influent concentration were $204 \mathrm{mg} \mathrm{NH}_{4}^{+}-\mathrm{N} / \mathrm{L}$ and $209 \mathrm{mg} \mathrm{NO}_{2}^{-}-\mathrm{N} / \mathrm{L}$.

from 32 to $346 \mathrm{mg} \mathrm{NH}_{4}^{+}-\mathrm{N} / \mathrm{L}$ and from 24 to $456 \mathrm{mg} \mathrm{NO}_{2}^{-}-\mathrm{N} / \mathrm{L}$, respectively (Table 2). During the first 32 days of operation, $1.4 \mathrm{mg} \mathrm{N}_{2} \mathrm{H}_{4}-\mathrm{N} / \mathrm{L}$ and $0.7 \mathrm{mg} \mathrm{NH} \mathrm{NH}_{2} \mathrm{OH}-\mathrm{N} / \mathrm{L}$ were added for enhancing the enrichment of anammox biomass, since those compounds can restore the metabolic functions of anammox bacteria [8]. The medium was maintained in a glass vessel at $4^{\circ} \mathrm{C}$ throughout the filling process.

\subsection{Analytical Procedures and Molecular Analyses}

Ammonium, nitrate and nitrite were analyzed by flow injection analysis (FIA), in accordance with APHA [9]. The biomass concentration (as volatile suspended solids-VSS-concentration) was also measured according to APHA [9]. Specific anammox activity (SAA) was estimated from the slope of the curve describing the $\mathrm{NH}_{4}^{+}-\mathrm{N}$ consumption as a function of time and related to the biomass concentration in $250 \mathrm{~mL}$ flasks filled with $90 \mathrm{~mL}$ of medium and $10 \mathrm{ml}$ of anammox biomass.

Biomass samples were collected for $16 \mathrm{~S}$ rRNA gene analysis, at the end of strategy $\mathrm{S}_{3}\left(170^{\text {th }}\right.$ day of operation), which aimed for biomass increasing, and during strategy $\mathrm{S}_{5.4}$, which presented high anammox activity (450 ${ }^{\text {th }}$ day of operation). The DNA samples were amplified separately via PCR using anammox-specific $\left(170^{\text {th }}\right.$ day of operation) and universal primers ( $450^{\text {th }}$ day of operation), and the products were employed for the construction of $16 \mathrm{~S}$ rDNA clone libraries. DNA segments consisting of approximately 780 base pairs (bp) of the 16S rRNA gene were PCR amplified using specific primers for anammox (46Frc-AMX820R) and the universal primers (6F/1510R) [10] according to the method described by [11].

Extraction of total DNA was performed using the modified phenol-chloroform protocol described by [12]. The obtained PCR products were inserted into plasmids using the pGEM-T Easy Vector System. Competent $\mathrm{DH} 5 \alpha$ E. coli cells were transformed with the plasmids (according to the manufacturer instructions) and clones 
were randomly selected. Nucleotide sequencing was performed in an ABI 310 PRISM DNA sequencer using the M13 forward primer. The obtained sequences were grouped and aligned using CLUSTALW [13]. After alignment, a distance matrix was created, which allowed the DOTUR software [14] to calculate the number of OTUs present at a 3\% dissimilarity level. The sequences were compared with sequences in the NCBI database, to determine the phylogenetic identity of the clones, and a phylogenetic tree was created with the ARB software [15], using the Lanemask PH filter and Thermothoga maritima as the outgroup.

The sequences of each OTU determined in this study were deposited in GenBank under accession numbers JQ609072 to JQ609091.

\section{Results and Discussion}

\subsection{Operation of the Reactor}

During the operation under strategy $\mathrm{S}_{1.1}$, no conversion of ammonium and nitrite was observed, since the $\mathrm{pH}$ values reached values up to 9.1, which is higher than the optimal values (7.0 - 8.5) [6] [16]. Despite the later pH decrease to 7.8 by sparging an $\mathrm{Ar} / \mathrm{CO}_{2}(97 \% / 3 \%)$ mixture, the nitrogen removal was still low $(14 \% \pm 6 \%$ ) between the $45^{\text {th }}$ and $55^{\text {th }}$ day of operation. After 56 days of operation, the influent nitrogen concentration was reduced by half to avoid possible nitrite inhibition $\left(S_{1.2}\right)$. Under strategy $S_{1.2}$, ammonium removal $(37 \% \pm 10 \%)$, but not nitrite removal, could be observed (Figure 1). The ammonium removal during strategy $\mathrm{S}_{1.2}$ was due to
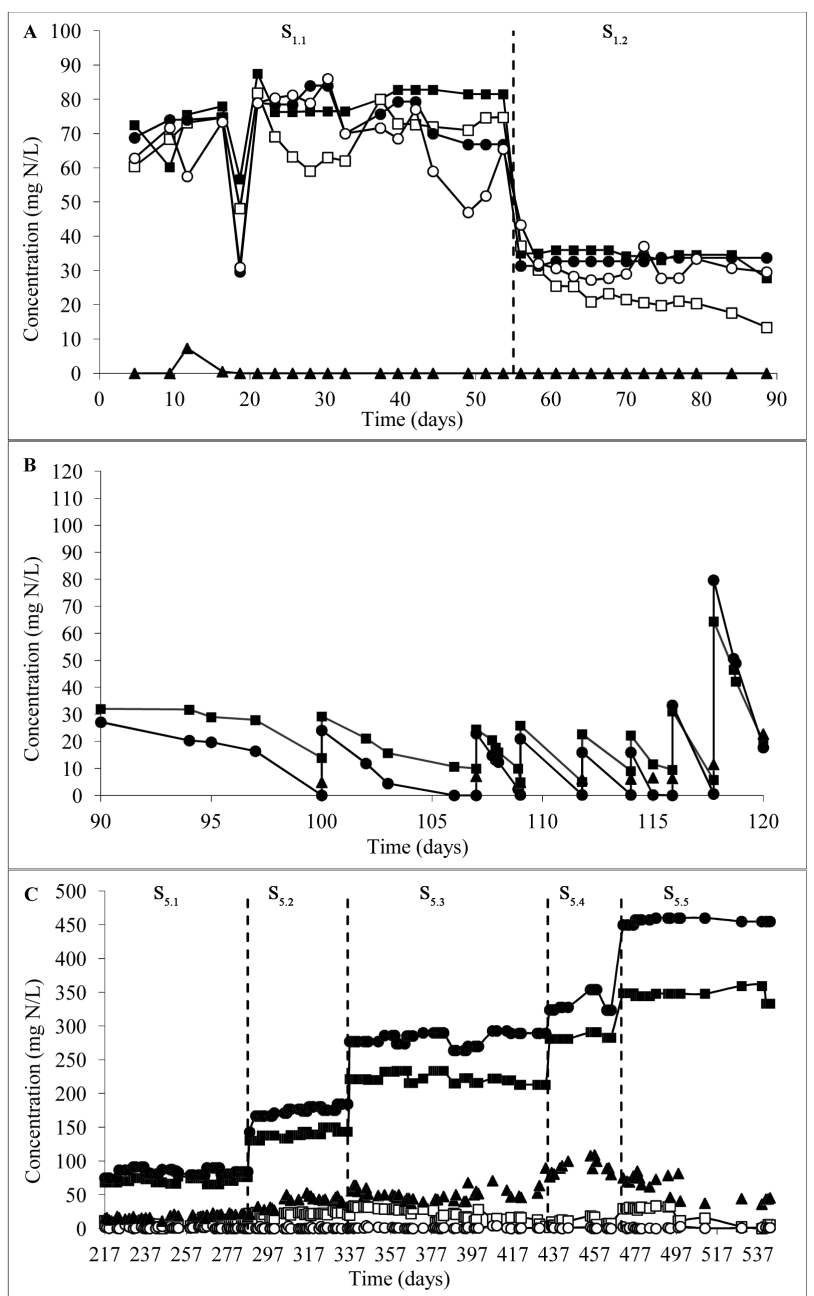

Figure 1. Influent and effluent concentrations of nitrogen compounds under strategy $\mathrm{S}_{1}(\mathrm{~A}), \mathrm{S}_{2}(\mathrm{~B})$ and $\mathrm{S}_{5}(\mathrm{C})$. Ammonium influent (匹), ammonium effluent $(\square)$, nitrite influent $(\bullet)$, nitrite effluent $(\circ)$ and nitrate effluent $(\boldsymbol{\Delta})$. 
nitrification, which was verified by the presence of oxidized nitrogen compounds on the $89^{\text {th }}$ day of operation (data not shown). Additionally, it was observed a biomass decrease at the end of strategy $\mathrm{S}_{1.1}$ ( $55^{\text {th }}$ day of operation, Figure 2), probably due to the washing out of heterotrophic biomass. At this point, the reactor was filled for 12 hours, during which the ammonium concentration remained relatively constant, and nitrite levels increased until the $14^{\text {th }}$ hour. Based on this observation, it was inferred that oxygen entered the reactor headspace during effluent withdrawal, allowing nitrification to occur until all of the dissolved oxygen had been consumed. Ammonium removal continued from this point, as $2.2 \mathrm{mg} \mathrm{NH}_{4}^{+}-\mathrm{N} / \mathrm{L}$ was observed to be removed until the end of this cycle without nitrification. For this reason, from this point on, a mixture of $\mathrm{Ar} / \mathrm{CO}_{2}$ gases was continuously sparged into the reactor headspace to prevent the entry of oxygen.

Under strategy $\mathrm{S}_{2}$, the SBR reaction time was determined by the observation of total consumption of nitrite (Figure 1(b)). Initially, the nitrogen compounds consuming time was 10 days. At the second batch of strategy $\mathrm{S}_{2}$, the reaction time decreased to six days, although a significant removal (total nitrogen removal rate of $60 \%$ ) was obtained within 3 days. From the third batch on, the reaction time was established within two days, even when the concentrations of these compounds were increased punctually to approximately $80 \mathrm{mg} \mathrm{NO}_{2}^{-}-\mathrm{N} / \mathrm{L}$ and $65 \mathrm{mg}$ $\mathrm{NH}_{4}^{+}$-N/L. The results obtained during strategy $\mathrm{S}_{2}$ indicated that nitrogen compounds concentration were adequate to obtain anammox activity after three months, similar to [17] and [18]. Moreover, the total nitrogen removal rate $(60 \%)$ between the $118^{\text {th }}$ and the $120^{\text {th }}$ day of operation indicated a potential to remove higher nitrogen loads.

Under strategy $\mathrm{S}_{3}\left(121^{\text {st }}\right.$ to $179^{\text {th }}$ day), the nitrite and ammonium concentrations were increased to approximately $210 \mathrm{mg}$ of $\mathrm{NO}_{2}^{-}-\mathrm{N} / \mathrm{L}$ and $210 \mathrm{mg}$ of $\mathrm{NH}_{4}{ }^{+}-\mathrm{N} / \mathrm{L}$, employing a 7-day cycle and constant reactor filling, except during settling and withdrawal (feed batch). The fed batch, in this case, was employed to maintain the same ANL as the one under the $S_{1.1}$ strategy. Although almost $100 \%$ nitrogen removal was achieved, no increase of biomass was observed, since VSS concentrations in SBR were $0.66 \pm 0.03$ and $0.55 \pm 0.18 \mathrm{~g}$ VSS/L on the $112^{\text {nd }}$ and $177^{\text {th }}$ days of operation, respectively. Probably, biomass increase was not observed because there was no increase of the ANL under strategy $\mathrm{S}_{3}(60 \mathrm{mg} \mathrm{N} / \mathrm{L} \cdot \mathrm{d})$.

Since increase of biomass was not achieved during strategy $\mathrm{S}_{3}$, influent concentrations was returned to approximately $67 \mathrm{mg}$ of $\mathrm{NH}_{4}^{+}-\mathrm{N} / \mathrm{L}$ and $64 \mathrm{mg} \mathrm{NO}_{2}^{-}-\mathrm{N} / \mathrm{L}$ (strategy $\mathrm{S}_{4}$ ). Ammonium and nitrite removal were $66 \% \pm 27 \%$ and $95 \% \pm 9 \%$, respectively, resulting in effluent concentrations of $2 \pm 4 \mathrm{mg} \mathrm{NO} \mathrm{NO}_{2}^{-}-\mathrm{N} / \mathrm{L}$ and $18 \pm$ $14 \mathrm{mg}$ of $\mathrm{NH}_{4}^{+}-\mathrm{N} / \mathrm{L}$. The end of strategy $\mathrm{S}_{4}$ was considered to be the end of the biomass enrichment process, due to the high $\mathrm{N}$ removal efficiencies obtained.

The main aspect that should be addressed at anammox biomass enrichment is the focus on maintaining anaerobiosis in the system including headspace. The main issues related to obtaining anammox activity under strategy $S_{1}$ were related to allowing oxygen inside the SBR. Another important aspect to be considered is to gradually increase the ANL coupled with the gradually decrease of reaction time, according to the consumption of nitrite and ammonium.

At steady state reactor operation, five steps were adopted (strategy $S_{5}$ ), by increasing the ANL up to $802 \mathrm{mg}$ $\mathrm{N} / \mathrm{L} \cdot \mathrm{d}$, with total nitrogen removal efficiencies between $80 \%$ and $90 \%$ (Table 3). Under strategies $\mathrm{S}_{5.1}, \mathrm{~S}_{5.2}$ and

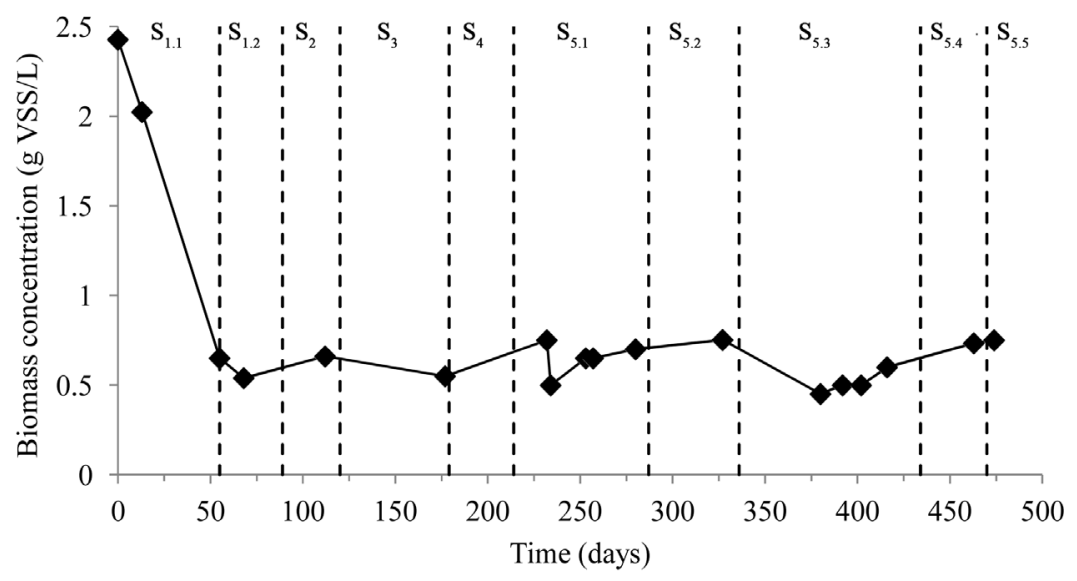

Figure 2. Volatile Suspended Solids (VSS) concentration in the SBR. 
Table 3. ANL, nitrogen load removed and total nitrogen removal during strategy $\mathrm{S}_{5}$.

\begin{tabular}{cccc}
\hline Strategy & ANL $(\mathrm{mg} \mathrm{N} / \mathrm{L} \cdot \mathrm{d})$ & Nitrogen load removed $(\mathrm{mg} \mathrm{N} / \mathrm{L} \cdot \mathrm{d})$ & Total nitrogen removal $(\%)$ \\
\hline $\mathrm{S}_{5.1}$ & $155 \pm 6$ & $133 \pm 12$ & $82.0 \pm 3.5$ \\
$\mathrm{~S}_{5.2}$ & $314 \pm 12$ & $264 \pm 21$ & $80.3 \pm 2.9$ \\
$\mathrm{~S}_{5.3}$ & $504 \pm 13$ & $436 \pm 28$ & $85.1 \pm 2.5$ \\
$\mathrm{~S}_{5.4}$ & $619 \pm 18$ & $516 \pm 13$ & $83.4 \pm 2.0$ \\
$\mathrm{~S}_{5.5}$ & $802 \pm 8$ & $719 \pm 28$ & $89.6 \pm 3.4$ \\
\hline
\end{tabular}

$\mathrm{S}_{5.3}$, it could be seen that, as the ANL increased from 155 to $504 \mathrm{mg} \mathrm{N} / \mathrm{L} \cdot \mathrm{d}$, the SAA increased as well from 8.3 to $31.6 \mathrm{mg} \mathrm{NH}_{4}^{+}-\mathrm{N} / \mathrm{g}$ VSS·h (Table 4). The increase of the SAA up to strategy $\mathrm{S}_{5.3}$ was coupled to an increase of nitrite removed/ammonium removed ratio (N-Nitrite/N-Ammonium) and a decrease of nitrate produced/ ammonium removed ratio (N-Nitrate/N-Ammonium) (Figure 3). Employing a stoichiometric influent ratio may improve specific anammox activity [19]. Between strategies $S_{5.1}$ and $S_{5.3}$, the N-Nitrite/N-Ammonium ratio increased from $1.31 \pm 0.12$ to $1.40 \pm 0.07$ and the N-Nitrate/N-Ammonium ratio decreased from $0.29 \pm 0.06$ to $0.26 \pm 0.05$. At strategy $S_{5.3}$, the N-Nitrite/N-Ammonium was higher than the theoretical ratio (1.32) and the $\mathrm{N}$-Nitrate/N-Ammonium ratio approached the theoretical value (0.26) [20]. Moreover, the SAA after $\mathrm{S}_{5.1}$ increased 4-fold at $S_{5.3}$ suggesting that the proportion of the anammox bacterial population within the microbial consortium had increased (Table 4), despite the fact that the biomass concentration (VSS) remained stable (Figure 2).

At strategy $\mathrm{S}_{5.4}$, the SAA was $29.4 \mathrm{mg} \mathrm{NH}_{4}^{+}-\mathrm{N} / \mathrm{g}$ VSS·h, which is similar to $\mathrm{S}_{5.3}$. On the $473^{\text {th }}$ day of operation (strategy $S_{5.5}$ ) the SAA was lower than the ones obtained in the $S_{5.3}$ and $S_{5.4}$, probably due to nitrite inhibition.

Nitrite concentration on the second hour of cycle was $296.5 \mathrm{mg} \mathrm{NO}_{2}^{-}-\mathrm{N} / \mathrm{L}$. Reference [21] observed inhibition at concentrations greater than $244 \mathrm{mg} \mathrm{NO}_{2}^{-}-\mathrm{N} / \mathrm{L}$, while [22] reported that $400 \mathrm{mg} \mathrm{NO}_{2}^{-}-\mathrm{N} / \mathrm{L}$ reduced in $50 \%$ the activity of granular biomass. Nevertheless, the SAA was $24.9 \mathrm{mg} \mathrm{NH}_{4}^{+}-\mathrm{N} / \mathrm{g} \mathrm{VSS} \cdot \mathrm{h}$ under strategy $\mathrm{S}_{5.5}$, even at higher nitrite influent concentrations (456 $\pm 14 \mathrm{mg} \mathrm{NO}_{2}^{-}-\mathrm{N} / \mathrm{L}$ ). The effluent nitrate concentrations were significantly lower than it would be expected, based on anammox metabolism, since it was observed a $\mathrm{N}$-Nitrate/ N-Ammonium ratio of $0.19 \pm 0.05$. Because of the lower concentrations of nitrate in the effluent, it was observed the highest total nitrogen removal rate under strategy $S_{5.5}(89.6 \%)$. Probably, nitrate-reducing activity was likely occurring during strategy $S_{5.5}$. Anammox bacteria may have carried out this nitrate reduction: they exhibit a denitrifying pathway in which nitrate is reduced (using residual organic carbon) to ammonium via nitrite, which is then transformed into molecular nitrogen $\left(\mathrm{N}_{2}\right)$ [23].

Therefore, nitrate may have been reduced to molecular nitrogen by the aforementioned pathway, since the effluent concentrations of ammonium were also reduced (i.e., nitrate generated via anammox activity was reduced to nitrite— by nitrate-reducing activity—and removed together with the remaining ammonium via anammox activity) (Figure 1(c)). Additionally, the observed nitrate reduction may also be due to other nitrate-reducing organisms (e.g., Pseudomonas sp. or other Proteobacteria species).

\subsection{Bacterial Diversity}

A total of 21 anammox-like 16S rDNA sequences were obtained after 170 days of operation. The sequences from 21 clones were grouped into two OTUs. OTU esp 1 (19 sequences) was 99\% similar to Brocadia sinica and 92\% similar to B. anammoxidans. OTU esp 2 (two sequences) showed 99\% similarity to Anammoxoglobus propionicus. Figure 4 shows the phylogenetic tree containing the described OTUs.

The phylogenetic tree depicted in Figure 4 also contains the OTUs found in the SBR after 450 days of operation. The OTUs were divided into six major bacterial groups: Planctomycete, beta-Proteobacteria, green sulfur bacteria of the Chlorobi phylum, Nitrospira, Chloroflexi and the OP 11 candidate phylum. In a metagenomic study carried out by [24], the following groups were found in anammox biomass: alpha-, beta-, gamma- and delta-Proteobacteria, Acidobacteria, Chloroflexi, Chlorobi, Bacteroidetes, Planctomycetes and the OP 11 candidate phylum. 


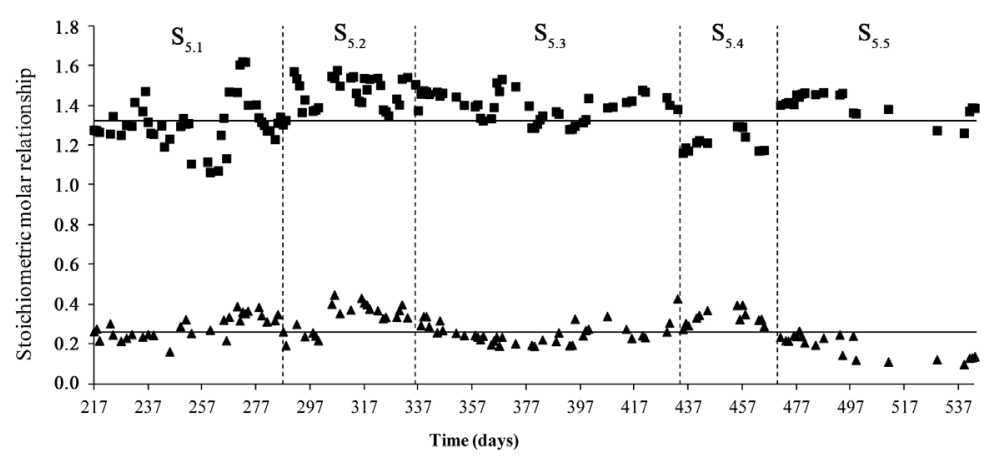

Figure 3. Stoichiometric ratio of nitrite removed/ammonium removed ( $\mathbf{\square})$ and nitrate produced/ammonium removed $(\boldsymbol{\Delta})$ under strategy S5. Solid lines represent the theoretical molar ratio.

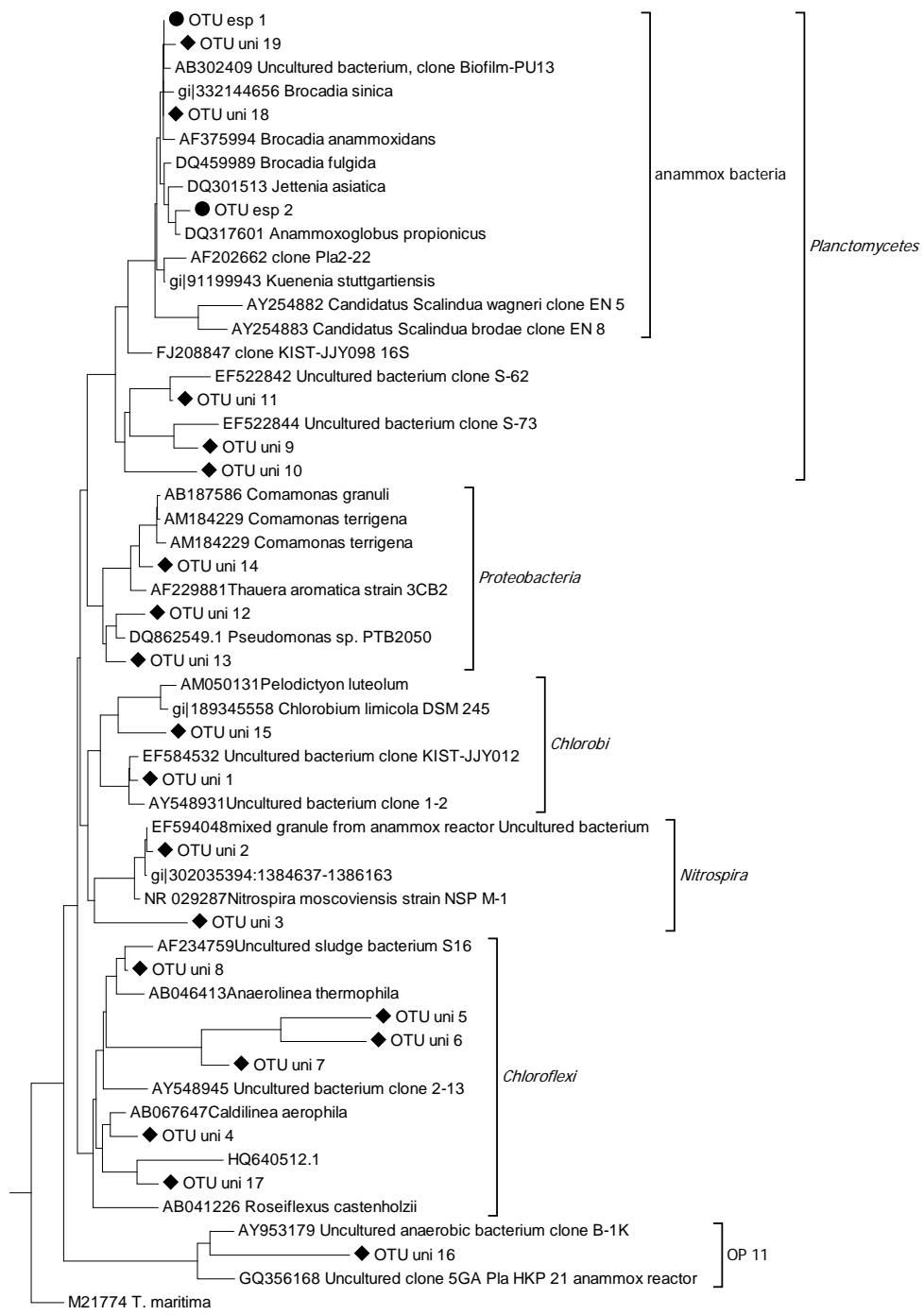

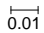

Figure 4. Phylogenetic tree of the examined 16S rRNA gene fragments based on OTUs esp 1 and $2(\bullet)$ and OTUs uni $1-19(\diamond)$ found in samples from the SBR. Thermotoga maritima was used as the outgroup; the bar indicates one substitution per 100 nucleotides. The ARB program tree was constructed using a LanemaskPH filter. 
Table 4. Applied nitrogen load (ANL), nitrogen load removed and total nitrogen removal during strategy $\mathrm{S}_{5}$.

\begin{tabular}{|c|c|c|c|}
\hline Strategy (day tested) & $\mathrm{SAA}\left(\mathrm{mg} \mathrm{NH}_{4}^{+}-\mathrm{N} / \mathrm{g} \mathrm{VSS} \cdot \mathrm{h}\right)$ & Influent ammonium (mg $\left.\mathrm{NH}_{4}^{+}-\mathrm{N} / \mathrm{L}\right)$ & Influent nitrite (mg $\left.\mathrm{NO}_{2}^{-}-\mathrm{N} / \mathrm{L}\right)$ \\
\hline $\mathrm{S}_{5.1}\left(253^{\text {th }}\right)$ & $8.3 \pm 1.0$ & $83 \pm 5$ & $77 \pm 4$ \\
\hline $\mathrm{S}_{5.2}\left(331^{\mathrm{th}}\right)$ & $13.4 \pm 1.6$ & $185 \pm 8$ & $143 \pm 6$ \\
\hline $\mathrm{S}_{5.3}\left(381^{\text {th }}\right)$ & $31.6 \pm 1.8$ & $290 \pm 9$ & $234 \pm 4$ \\
\hline $\mathrm{S}_{5.4}\left(465^{\mathrm{th}}\right)$ & $29.4 \pm 1.7$ & $323 \pm 9$ & $283 \pm 4$ \\
\hline$S_{5.5}\left(473^{\text {th }}\right)$ & $24.9 \pm 1.2$ & $450 \pm 4$ & $349 \pm 7$ \\
\hline
\end{tabular}

It is likely that the OTU uni 12 - 14 clones, which contain sequences related to Pseudomonas and Comamonas, exhibited nitrate-reducing activity (as suggested by the results from $\mathrm{S}_{5.5}$ ). References [25] [26] showed that uncultured Nitrospira sp. could fix $\mathrm{CO}_{2}$ to produce pyruvate, but not acetate, butyrate or propionate in activated nitrifying sludge. Therefore, this unusual type of Nitrospira sp. metabolism indicates that short-chain organic acids may have acted as electron donors for nitrate-reducing microorganisms.

However, after 450 days of operation, Brocadia-like clones out-competed Anammoxoglobus propionicus. Reference [27] described a new species of anammox bacteria showing a different type of metabolism than had been previously described. They reported that $A$. propionicus could co-oxidize ammonium and propionic acid and presented a specific propionic acid removal rate of $0.64 \mathrm{mmol} / \mathrm{g}$ protein.min. Surprisingly, two anammox bacteria species were found in the SBR after 170 days of operation, but only the Brocadia species remained in the reactor after 450 days of operation. After long term period of SBR operation residual organic carbon of endogenous origin may not have been present, explaining the ability of Brocadia-like species to out-compete A. propionicus.

\section{Conclusion}

The results obtained in this study showed that sludge obtained from a pilot scale reactor treating amino-acid was a suitable inoculum source for enriching an anammox biomass. Maintaining anaerobiosis in the SBR and increasing ANL while decreasing reaction time were crucial procedures for successfully establishing the process. The SBR reached the conversion efficiency of $98.4 \%$ and nitrogen load removed of an average of $518.9 \mathrm{~g}$ $\mathrm{N} / \mathrm{m}^{3}$-day. A suitable approach to obtain a high biomass activity was to increase ANL coupled to an adequate influent $\mathrm{NO}_{2}^{-}-\mathrm{N} / \mathrm{NH}_{4}^{+}-\mathrm{N}$ ratio (near to 1.32 at $\mathrm{S}_{5.1-5}$ ). Moreover specific anammox activity was only partially inhibited by high nitrite concentration (296.5 mg $\mathrm{NO}_{2}^{-}-\mathrm{N} / \mathrm{L}$ ). After 170 days of operation, samples of the anammox biomass produced two OTUs: one was similar to B. sinica and the other was similar to Anammoxoglobus propionicus. Two species of anammox bacteria were found in the SBR with 170 days of operation, but only the Brocadia-like species remained in the SBR up to 470 days of operation, along with other species possibly related to the nitrogen cycle.

\section{Acknowledgements}

The authors gratefully acknowledge FAPESP (Fundação de Amparo à Pesquisa do Estado de São Paulo, Brazil) for financial support, CNPq (Conselho Nacional de Desenvolvimento Científico e Tecnológico, Brazil) for the grant, as well as Dr. Claudia Etchebehere and Dr. Dagoberto Yukio Okada for the careful reading of the manuscript.

\section{References}

[1] Mulder, A., Van Graaf, A.A., Robertson, L.A. and Kuenen, J.G. (1995) Anaerobic Ammonium Oxidation Discovered in a Denitrifying Fluidized-Bed Reactor. FEMS Microbiology Ecology, 16, 177-183. http://dx.doi.org/10.1111/j.1574-6941.1995.tb00281.x

[2] Jetten, M.S.M., van Dongen, L.G.J.M. and van Loosdrecht, M.C.M. (2001) The Combined Sharon/Anammox Process. IWA Publishing London, UK.

[3] Strous, M., Fuerst, J.A., Kramer, E.H.M., Logemann, S., Muyzer, G., van de Pas-Schoonen, K.T., Webb, R., Kuenen, J.G. and Jetten, M.S.M. (1999) Missing Lithotroph Identified as New Planctomycete. Nature, 400, 446-449. 
http://dx.doi.org/10.1038/22749

[4] Egli, K., Fanger, U., Alvarez, P.J.J., Siegrist, H., van der Meer, J.R. and Zehnder, A.J.B. (2001) Enrichment and Characterization of an Anammox Bacterium from a Rotating Biological Contactor Treating Ammonium-Rich Leachate. Archives of Microbiology, 175, 198-207. http://dx.doi.org/10.1007/s002030100255

[5] de Araujo, M.M. and Zaiat, M. (2009) An Upflow Fixed-Bed Anaerobic-Aerobic Reactor for Removal of Organic Matter and Nitrogen from L-Lysine Plant Wastewater. Canadian Journal of Civil Engineering, 36, 1085-1094. http://dx.doi.org/10.1139/L09-028

[6] Jetten, M.S.M., Wagner, M., Fuerst, J., van Loosdrecht, M., Kuenen, G. and Strous, M. (2001) Microbiology and Application of the Anaerobic Ammonium Oxidation (“anammox”) Process. Current Opinion in Biotechnology, 12, 283288. http://dx.doi.org/10.1016/S0958-1669(00)00211-1

[7] van Graaf, A.A.V., de Bruijn, P., Robertson, L.A., Jetten, M.S.M. and Kuenen, J.G. (1996) Autotrophic Growth of Anaerobic Ammonium-Oxidizing Micro-Organisms in a Fluidized Bed Reactor. Microbiology, 142, 2187-2196. http://dx.doi.org/10.1099/13500872-142-8-2187

[8] Strous, M., Kuenen, J.G. and Jetten, M.S.M. (1999) Key Physiology of Anaerobic Ammonium Oxidation. Applied and Environmental Microbiology, 65, 3248-3250.

[9] APHA, AWWA and WPCF (2005) Standard Methods for the Examination of Water and Wastewater. American Public Health Association, Washington DC.

[10] Schmid, M., Twachtmann, U., Klein, M., Strous, M., Juretschko, S., Jetten, M., Metzger, J.W., Schleifer, K.H. and Wagner, M. (2000) Molecular Evidence for Genus Level Diversity of Bacteria Capable of Catalyzing Anaerobic Ammonium Oxidation. Systematic and Applied Microbiology, 23, 93-106. http://dx.doi.org/10.1016/S0723-2020(00)80050-8

[11] Egli, K., Bosshard, F., Werlen, C., Lais, P., Siegrist, H., Zehnder, A.J.B. and van der Meer, J.R. (2003) Microbial Composition and Structure of a Rotating Biological Contactor Biofilm Treating Ammonium-Rich Wastewater without Organic Carbon. Microbial Ecology, 45, 419-432. http://dx.doi.org/10.1007/s00248-002-2037-5

[12] Griffiths, R.I., Whiteley, A.S., O’Donnell, A.G. and Bailey, M.J. (2000) Rapid Method for coextraction of DNA and RNA from Natural Environments for Analysis of Ribosomal DNA- and rRNA-Based Microbial Community Composition. Applied and Environmental Microbiology, 66, 5488-5491. http://dx.doi.org/10.1128/AEM.66.12.5488-5491.2000

[13] Larkin, M.A., Blackshields, G., Brown, N.P., Chenna, R., McGettigan, P.A., McWilliam, H., Valentin, F., Wallace, I.M., Wilm, A., Lopez, R., Thompson, J.D., Gibson, T.J. and Higgins, D.G. (2007) Clustal W and Clustal X Version 2.0. Bioinformatics, 23, 2947-2948. http://dx.doi.org/10.1093/bioinformatics/btm404

[14] Schloss, P.D. and Handelsman, J. (2005) Introducing DOTUR, a Computer Program for Defining Operational Taxonomic Units and Estimating Species Richness. Applied and Environmental Microbiology, 71, 1501-1506. http://dx.doi.org/10.1128/AEM.71.3.1501-1506.2005

[15] Ludwig, W., Strunk, O., Westram, R., Richter, L., Meier, H., Yadhukumar, Buchner, A., Lai, T., Steppi, S., Jobb, G., Forster, W., Brettske, I., Gerber, S., Ginhart, A.W., Gross, O., Grumann, S., Hermann, S., Jost, R., Konig, A., Liss, T., Lussmann, R., May, M., Nonhoff, B., Reichel, B., Strehlow, R., Stamatakis, A., Stuckmann, N., Vilbig, A., Lenke, M., Ludwig, T., Bode, A. and Schleifer, K.H. (2004) ARB: A Software Environment for Sequence Data. Nucleic Acids Research, 32, 1363-1371. http://dx.doi.org/10.1093/nar/gkh293

[16] Thuan, T.H., Jahng, D.J., Jung, J.Y., Kim, D.J., Kim, W.K., Park, Y.J., Kim, J.E. and Ahn, D.H. (2004) Anammox Bacteria Enrichment in Upflow Anaerobic Sludge Blanket (UASB) Reactor. Biotechnology and Bioprocess Engineering, 9, 345-351. http://dx.doi.org/10.1007/BF02933055

[17] Araujo, J.C., Campos, A.C., Correa, M.M., Silva, E.C., Matte, M.H., Matte, G.R., Von Sperling, M. and Chernicharo, C.A. (2011) Anammox Bacteria Enrichment and Characterization from Municipal Activated Sludge. Water Science and Technology, 64, 1428-1434. http://dx.doi.org/10.2166/wst.2011.632

[18] Lopez, H., Puig, S., Ganigue, R., Ruscalleda, M., Balaguer, M.D. and Colprim, J. (2008) Start-Up and Enrichment of a Granular Anammox SBR to Treat High Nitrogen Load Wastewaters. Journal of Chemical Technology and Biotechnology, 83, 233-241. http://dx.doi.org/10.1002/jctb.1796

[19] Martins, T.H. and Varesche, M.B.A. (2013) Specific Anammox Activity under Different Conditions (I): The Influence of Temperature and Initial Nitrogen Concentration. Proceedings of the 13th World Congress on Anaerobic Digestion: Recovering (bio) Resources for the World, IWA, Santiago de Compostela.

[20] Strous, M., Heijnen, J.J., Kuenen, J.G. and Jetten, M.S.M. (1998) The Sequencing Batch Reactor as a Powerful Tool for the Study of Slowly Growing Anaerobic Ammonium-Oxidizing Microorganisms. Applied Microbiology and Biotechnology, 50, 589-596. http://dx.doi.org/10.1007/s002530051340

[21] Magrí, A., Vanotti, M.B. and Szögi, A.A. (2012) Anammox Sludge Immobilized in Polyvinyl Alcohol (PVA) Cryogel Carriers. Bioresource Technology, 114, 231-240. http://dx.doi.org/10.1016/j.biortech.2012.03.077 
[22] Cho, S., Takahashi, Y., Fujii, N., Yamada, Y., Satoh, H. and Okabe, S. (2010) Nitrogen Removal Performance and Microbial Community Analysis of an Anaerobic Up-Flow Granular Bed Anammox Reactor. Chemosphere, 78, 11291135. http://dx.doi.org/10.1016/j.chemosphere.2009.12.034

[23] Kartal, B., Kuypers, M.M.M., Lavik, G., Schalk, J., den Camp, H., Jetten, M.S.M. and Strous, M. (2007) Anammox Bacteria Disguised as Denitrifiers: Nitrate Reduction to Dinitrogen Gas via Nitrite and Ammonium. Environmental Microbiology, 9, 635-642. http://dx.doi.org/10.1111/j.1462-2920.2006.01183.x

[24] Strous, M., Pelletier, E., Mangenot, S., Rattei, T., Lehner, A., Taylor, M.W., Horn, M., Daims, H., Bartol-Mavel, D., Wincker, P., Barbe, V., Fonknechten, N., Vallenet, D., Segurens, B., Schenowitz-Truong, C., Medigue, C., Collingro, A., Snel, B., Dutilh, B.E., Op den Camp, H.J.M., van der Drift, C., Cirpus, I., van de Pas-Schoonen, K.T., Harhangi, H.R., van Niftrik, L., Schmid, M., Keltjens, J., van de Vossenberg, J., Kartal, B., Meier, H., Frishman, D., Huynen, M.A., Mewes, H.W., Weissenbach, J., Jetten, M.S.M., Wagner, M. and Le Paslier, D. (2006) Deciphering the Evolution and Metabolism of an Anammox Bacterium from a Community Genome. Nature, 440, 790-794. http://dx.doi.org/10.1038/nature04647

[25] Daims, H., Nielsen, P.H., Nielsen, J.L., Juretschko, S. and Wagner, M. (2000) Novel Nitrospira-Like Bacteria as Dominant Nitrite-Oxidizers in Biofilms from Wastewater Treatment Plants: Diversity and in Situ Physiology. Water Science and Technology, 41, 85-90.

[26] Daims, H., Nielsen, J.L., Nielsen, P.H., Schleifer, K.H. and Wagner, M. (2001) In Situ Characterization of Nitrospira-Like Nitrite Oxidizing Bacteria Active in Wastewater Treatment Plants. Applied and Environmental Microbiology, 67, 5273-5284. http://dx.doi.org/10.1128/AEM.67.11.5273-5284.2001

[27] Kartal, B., Rattray, J., van Niftrik, L.A., van de Vossenberg, J., Schmid, M.C., Webb, R.I., Schouten, S., Fuerst, J.A., Damste, J.S.S., Jetten, M.S.M. and Strous, M. (2007) Candidatus “Anammoxoglobus Propionicus” a New Propionate Oxidizing Species of Anaerobic Ammonium Oxidizing Bacteria. Systematic and Applied Microbiology, 30, 39-49. http://dx.doi.org/10.1016/j.syapm.2006.03.004 
Scientific Research Publishing (SCIRP) is one of the largest Open Access journal publishers. It is currently publishing more than 200 open access, online, peer-reviewed journals covering a wide range of academic disciplines. SCIRP serves the worldwide academic communities and contributes to the progress and application of science with its publication.

Other selected journals from SCIRP are listed as below. Submit your manuscript to us via either submit@scirp.org or Online Submission Portal.
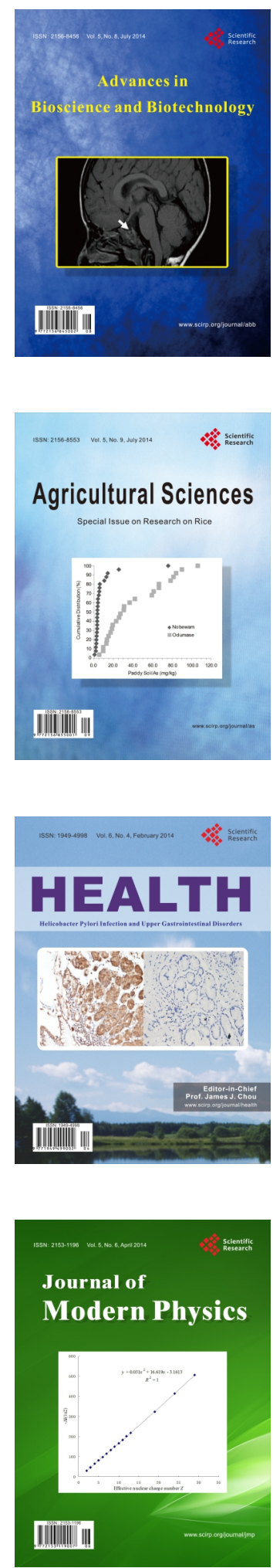
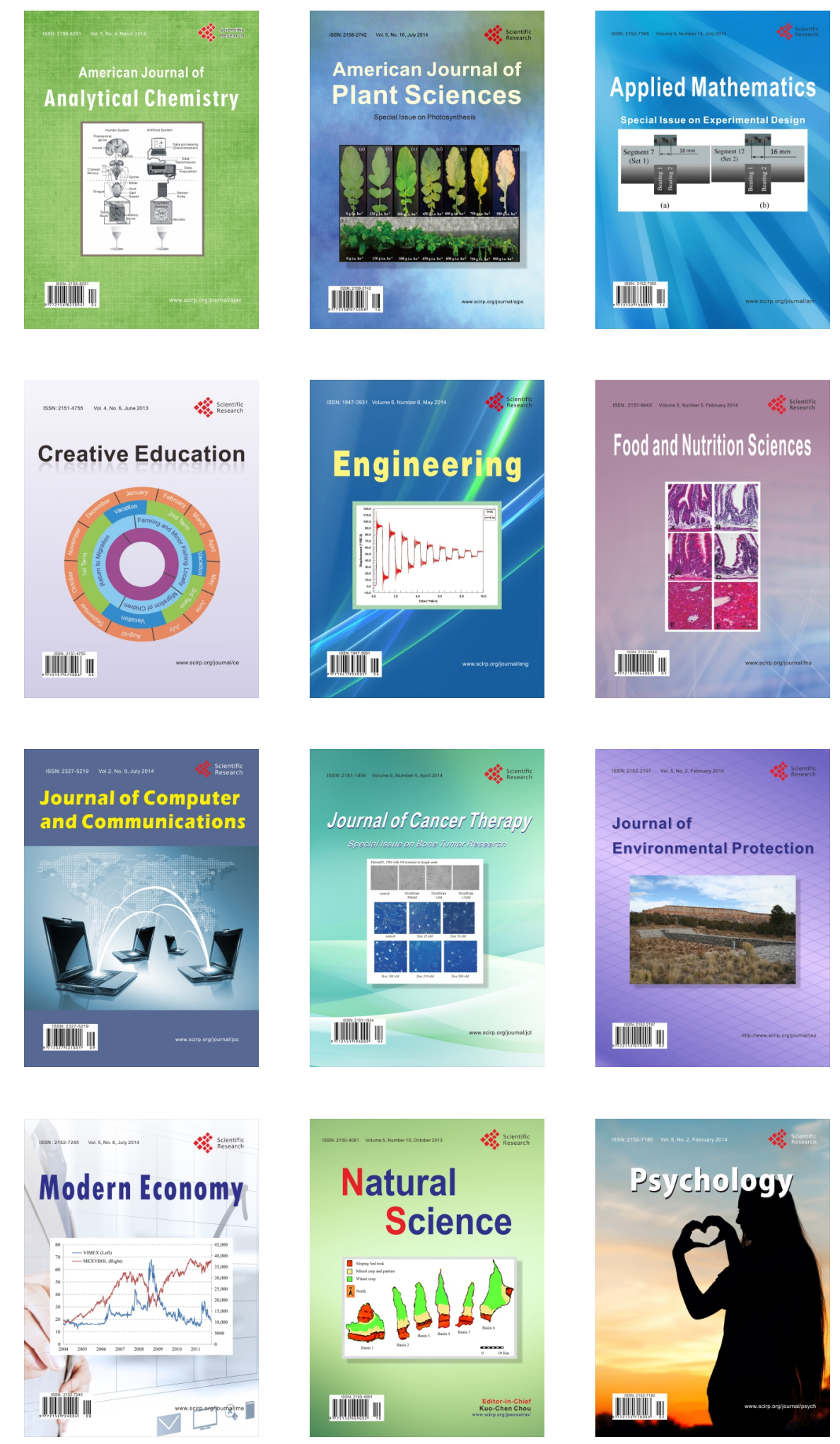